\title{
Soft Tissue Reconstruction with Reverse Flow Sural Flap in Pilon Fractures
}

\author{
Selami Serhat Sirvan', Kamuran Zeynep Sevim¹, Mehmet Mesut Sonmez², Isil Akgun Demir ${ }^{1}$, Daghan Dagdelen ${ }^{3}$, \\ Fatih Irmak1, Sevgi Kurt Yazar ${ }^{4}$ Semra Karsidag ${ }^{1}$
}

\begin{abstract}
:
Soft tissue reconstruction with reverse flow sural flap in pilon fractures

objective: Pilon fractures are usually caused by high-energy traumas and associated with surrounding soft tissue damage. In addition to the patient's medical state and comorbidities, the poor vascular supply of the distal tibia makes the reconstruction challenging in most of the cases.

Material and Methods: Eight patients with pilon fractures (AO types 43A-C) who were treated by the orthopaedics clinic between January 2012 and August 2015 were included in the study. These patients were consulted to our clinic due to full thickness soft tissue defect at the affected site during the operation, and were treated with reverse flow sural flap. Patients were analyzed retrospectively in terms of age, etiology, size of defect and postoperative complications.

Results: Between January 2012 and August 2015, 8 patients (4 females, 4 males) aged between 7 and 88 years (mean age: 46 years) underwent soft tissue reconstruction with reverse flow sural flap, due to tissue defect occurred after the pilon fracture. In the postoperative period, complications such as wound dehiscence, flap loss and infection were not encountered in any patients except one, who developed partial soft tissue necrosis and healed by secondary intention.

Conclusion: Pilon fractures are among the most difficult fractures of the ankle to treat, and have a high complication rate. Sural flap is a reliable way to reconstruct distal tibial defects in single or multiple-stage approaches.
\end{abstract}

Keywords: Lower extremity reconstruction, pilon fracture, sural flap, tibial fracture

\section{ÖZET:}

Pilon fraktürlerinde ters akımlı sural flep ile yumuşak doku rekonstrüksiyonu Amaç: Pilon fraktürleri yüksek enerjili travmalardan kaynaklanır ve genellikle çevre yumuşak doku hasarı eşlik eder. Hastanın genel durumu ve eşlik eden hastalıkları haricinde, tibial bölgenin damarlanmasının zayıf olması birçok vakada rekonstrüksiyonun zor olmasına sebep olur.

Gereç ve Yöntemler: Ocak 2012 ile Ağustos 2015 tarihleri arasında Ortopedi Kliniği tarafından AO 43A-C pilon fraktürü nedeniyle tedavi edilen 8 hasta çalışmaya alındı. Hastalar kliniğimize operasyon alanında tam kat yumuşak doku defekti nedeniyle danışıldı ve ters akımlı sural flep ile rekonstrüksiyon uygulandı. Hastalar geriye dönük olarak; yaş, etiyoloji, defekt çapı ve komplikasyonlar açısından incelendi.

Bulgular: Ocak 2012 ile Ağustos 2015 yılları arasında 8 hastaya (4 kadın, 4 erkek) pilon fraktürü sonrasında gelişen yumuşak doku defekti nedeniyle ters akımlı sural flep ile rekonstrüksiyon uygulandı. Postoperatif dönemde bir hastada parsiyel flep nekrozu izlendi ve sekonder iyileşme ile düzelirken, yara ayrışması, total flep kaybı ve enfeksiyon gibi komplikasyonlar hiçbir hastada izlenmedi.

Sonuç: Pilon kırıkları ayak bileğinin komplikasyon oranı yüksek ve tedavisi en zor kırıklarındandır. Sural flep; distal tibial bölgenin rekonstrüksiyonunda tek veya aşamalı olarak uygulanan güvenilir bir fleptir.

Anahtar kelimeler: Alt ekstremite rekonstrüksiyonu, pilon kırı̆̆ı, sural flep, tibia kırığı

Ş.E.E.A.H. Tıp Bülteni 2017;51(2):102-8
'University of Health Sciences, Sisli Hamidiye Etfal Training and Research Hospital, Department of Plastic, Reconstructive and Aesthetic Surgery, Istanbul - Turkey ${ }^{2}$ University of Health Sciences, Sisli Hamidiye Etfal Training and Research Hospital, Department of Orthopedic Surgery, Istanbul - Turkey

${ }^{3}$ Balikesir Governmental Hospital, Department of Plastic, Reconstructive and Aesthetic Surgery, Balikesir - Turkey

${ }^{4}$ University of Health Sciences, Samatya Training and Research Hospital, Plastic Reconstructive and Aesthetic Surgery, Istanbul - Turkey

Address reprint requests to / Yazışma Adresi: Selami Serhat Sirvan,

University of Health Sciences, Sisli Hamidiye Etfal Research and Training Hospital, Department of Plastic, Reconstructive and Aesthetic Surgery, Istanbul - Turkey

E-mail / E-posta: selamisirvan@gmail.com

Date of receipt / Geliş tarihi: January 23, 2017 / 23 Ocak 2017

Date of acceptance / Kabul tarihi: March 28, 2017 / 28 Mart 2017 


\section{INTRODUCTION}

Pilon fracture describes intra-articular fracture of distal tibial, distal tibia metaphysis or both. Approximately $30 \%$ of pilon fractures result from high-energy traumas such as car accidents, fall from height or industrial accidents, and often degloving soft tissue injuries accompany these fractures. Reconstruction of soft tissue defects involving foot and ankle region is still a challenging subject for orthopaedic and plastic surgeons. Recent developments in external and internal bone fixation techniques and the use of circular external fixators are a great help to preserve soft tissues and to prevent further damage to tissues traumatized previously. Soft tissues defects, that are treated inappropriately, may result in superficial or deep infections, osteomyelitis, and amputation in advanced stage.

In our study, we aimed to share our experience in soft tissue reconstruction with reverse flow sural flap in patients, who were treated in our orthopaedics clinic with the diagnosis of AO type 43A-C pilon fracture.

\section{MATERIAL AND METHODS}

Eight patients with pilon fractures (AO types 43AC) who were treated by the orthopaedics clinic between January 2012 and August 2015 were included in the study. These patients were consulted to our clinic due to full thickness soft tissue defect occurred at the site of the operation, and were treated with reverse flow sural flap. Patients were analyzed retrospectively in terms of age, etiology, size of defect and postoperative complications.

Depending on the age and the general medical status, patients were operated either under general or spinal anesthesia in prone position. Two-staged operation was planned, the first, consisting of the debridement of the soft tissue defect and flap delay, and the second being the adaptation of the flap to the defect. During the first operation, the skin island of the sural flap was planned over the musculotendinous junction of the gastrocnemius muscle, and its diameter was determined as at least $20 \%$ more of the final defect size after the debridement. The pivot point for the flap rotation was marked approximately $5 \mathrm{~cm}$ proximal to the lateral malleolus, where the perforator artery was detected via hand-held Doppler ultrasound device. Thin skin flaps were elevated along the line where multiple Z-plasties were performed between the distal end of the skin island of the flap and the point where the perforator artery was marked. For the delay procedure, the sural flap was elevated in subfascial plane (Figure-1,2). After the dissection of the sural nerve and vein, they both were ligated and by preserving the fat tissue around the sural artery, the adipofascial pedicle was raised with the flap as

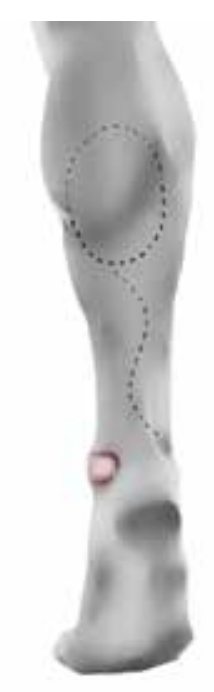

Figure-1: Schematic illustration of sural flap planning

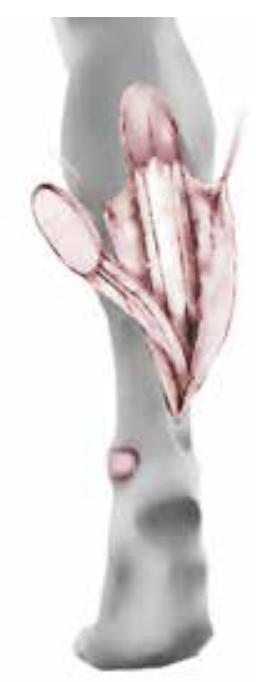

Figure-2: Schematic illustration of sural flap elevation 
Table-1: Patient informations

\begin{tabular}{|c|c|c|c|c|c|c|c|}
\hline $\begin{array}{l}\text { Patient } \\
\text { number }\end{array}$ & Age & Gender & Etiology & Defect Size & Complication & Smoking Status & $\begin{array}{l}\text { Diabetes } \\
\text { Mellitus }\end{array}$ \\
\hline 1 & 88 & Female & $\begin{array}{l}\text { Falling from } \\
\text { height }\end{array}$ & $6 \times 4 \mathrm{~cm}$ & None & None & - \\
\hline 2 & 7 & Male & Car accident & $3 \times 2 \mathrm{~cm}$ & None & None & - \\
\hline 3 & 26 & Male & $\begin{array}{c}\text { Falling from } \\
\text { height }\end{array}$ & $5 \times 3 \mathrm{~cm}$ & None & None & - \\
\hline 4 & 43 & Male & $\begin{array}{c}\text { Falling from } \\
\text { height }\end{array}$ & $3 \times 1 \mathrm{~cm}$ & None & Social & - \\
\hline 5 & 54 & Female & Car accident & $5 \times 4 \mathrm{~cm}$ & Partial necrorsis & None & + \\
\hline 6 & 20 & Female & $\begin{array}{c}\text { Falling from } \\
\text { height }\end{array}$ & $4 \times 4 \mathrm{~cm}$ & None & None & - \\
\hline 7 & 48 & Male & $\begin{array}{c}\text { Falling from } \\
\text { height }\end{array}$ & $5 \times 4 \mathrm{~cm}$ & None & 30 package/year & - \\
\hline 8 & 82 & Female & $\begin{array}{l}\text { Falling from } \\
\text { height }\end{array}$ & $5 \times 4 \mathrm{~cm}$ & None & None & - \\
\hline
\end{tabular}

well with its width being at least $25 \%$ of its length. After the flap was totally elevated, it was readapted to its original place. Negative pressure wound therapy (NPWT) was applied to the remaining tissue defect and once in every three days, the tissue defect was debrided and covered again with NPWT. Approximately 10 to 14 days later, the delayed sural flap was raised through the existing scars, rotated around the pivot point and adapted onto its new position over the tissue defect. The donor site of the flap was covered with split-thickness skin graft taken from the lateral thigh.

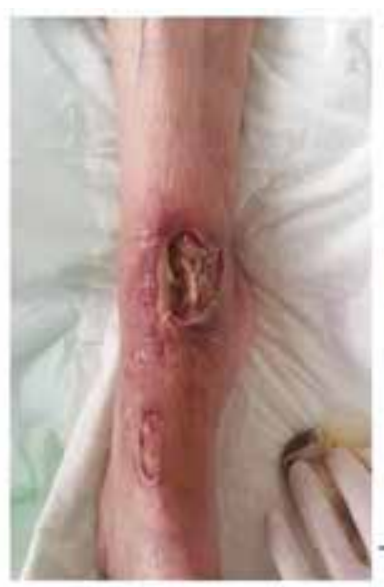

Preoperative

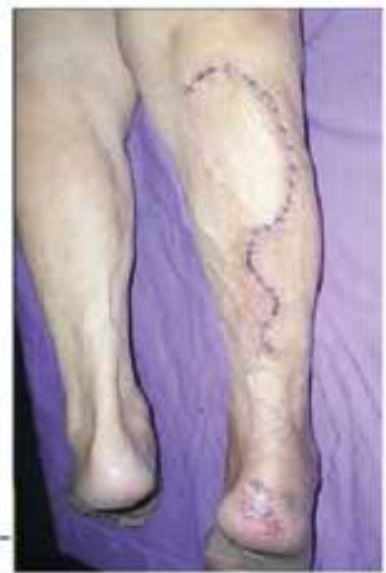

After flap delay

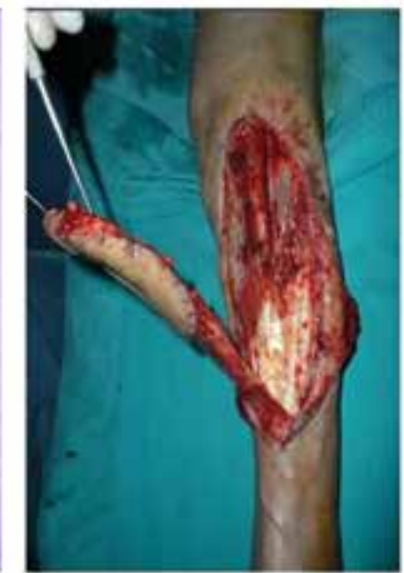

Peroperative

(Second operation)

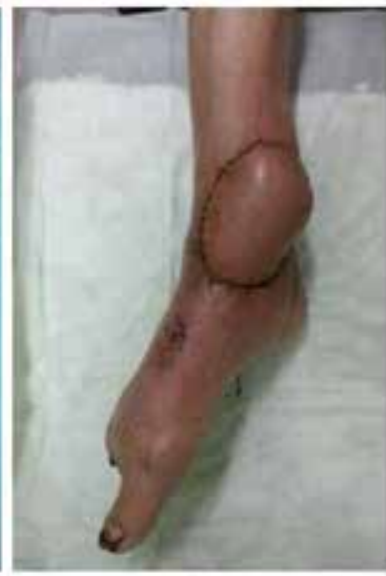

Postoperative 1 month

Figure-3: Preoperative, peroperative and postoperative pictures of the patient 


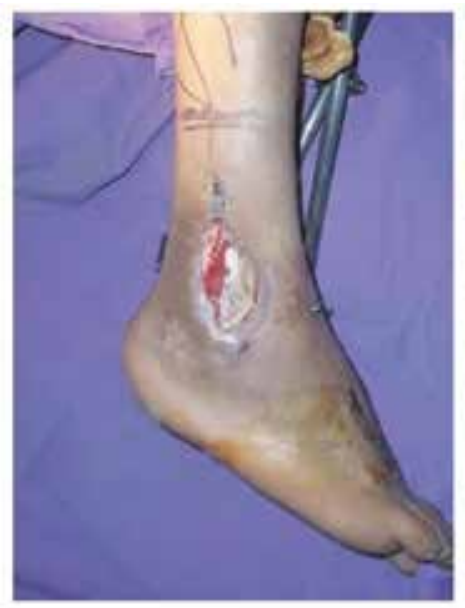

Preoperative

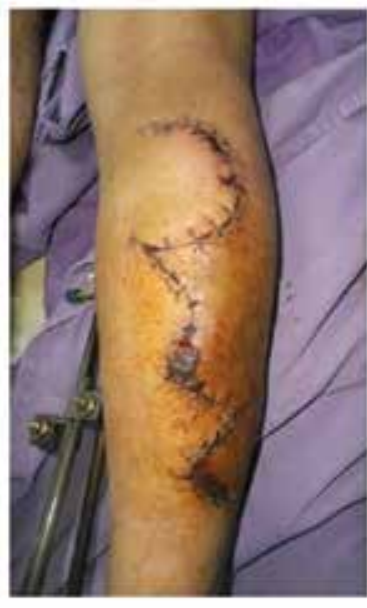

After Flap Delay

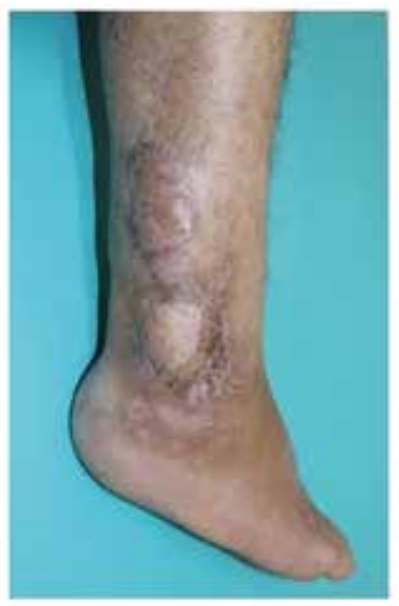

Postoperative 5. month

Figure-4: Preoperative, peroperative and postoperative pictures of the patient

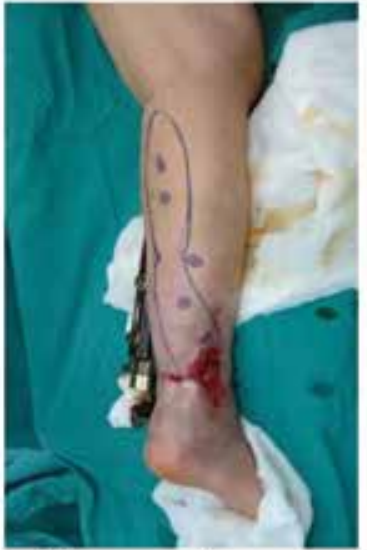

Preoperative

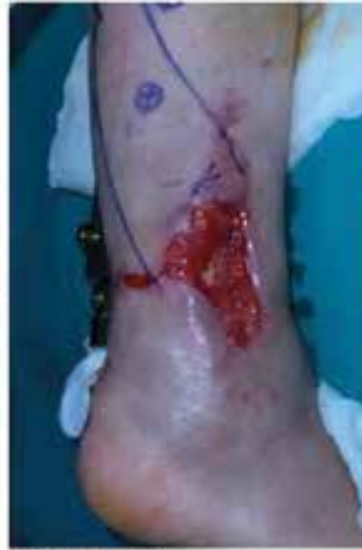

Defect in zoom

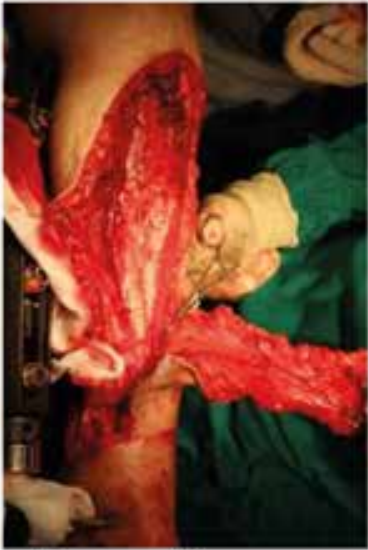

Peroperative

(Mosquito clamp under the pedicule)

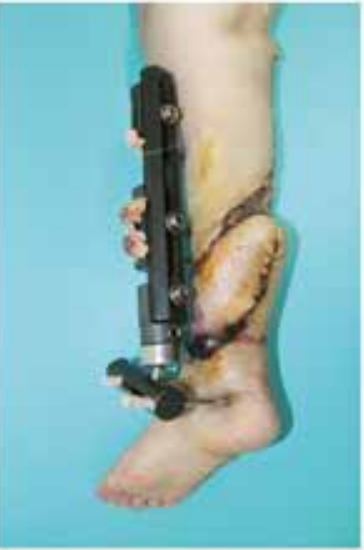

Postoperative 2. week (Partial necrosis)

Figure-5: Preoperative, peroperative and postoperative pictures of the patient

the first stage, and osteosynthesis at the second). The defect sizes at the initial examination ranged from $3 \times 1 \mathrm{~cm}$ to $6 \times 4 \mathrm{~cm}$ (mean: $15.5 \mathrm{~cm}^{2}$ ). In the postoperative period, complications such as wound dehiscence, flap loss and infection were not encountered in any patients except one, who developed partial soft tissue necrosis and healed by secondary intention. Two of the patients were smokers, and 1 patient had diabetes (Table-1) (Figure-3,4,5).

\section{DISCUSSION}

The term "pilon fracture" was first used by Destot in 1911, and he likened the distal tibia to a mortar (1). In 1970s, Ruaf and Snider (2) used the term explosion fracture to describe this fracture of the distal tibia. Pilon fractures constitute $7 \%$ of all tibial fractures and $1 \%$ of all lower extremity fractures (3). Because of the poor arterial blood supply of the soft tissues and bone at the distal level of the tibia, 
fixation and reconstruction of the complex pilon fractures is challenging. Pilon fracture is one of the most serious lower extremity injuries involving the ankle, and the question of how they should be treated it is still being debated.

While the current technical developments help the orthopaedic surgeon to provide better fixation, they also refer to the plastic surgeon for a much safer reconstruction by preserving soft tissues including skin as much as possible and preventing further trauma to the tissues that are already traumatized heavily (4).

The complications after an early open reduction and internal fixation (ORIF) of pilon fractures are partial or total necrosis of the soft tissues, wound dehiscence, osteomyelitis and amputation (3,5-8). Until 1969, the rate of acceptable results in pilon fractures that were treated conservatively was below $50 \%$ (9). In 1959, Jergesen (10) advocated that it was impossible to stabilize severe pilon fractures with ORIF. In 1969, Ruedi and Alloguer (9) reported 74\% success rate in 84 patients, who underwent early surgical intervention, yet $71 \%$ of fractures were caused by low energy trauma. A following study conducted by Teeny and Wis showed (8) $25 \%$ good and $25 \%$ intermediate results in 60 patients with pilon fracture which resulted from high-energy trauma, and at least one major complication in 50\% of patients during 30-month follow-up period. In 1984, Gustilo and Anderson (11) emphasized the importance of healthy soft tissue presence peripheral to the fracture site and how it affects the prognosis. They also developed a new classification for open tibial fractures with regard to coexisting soft tissue damage, which also shows that soft tissue status has greater importance on the prognosis than the bone fixation does $(11,12)$. Lately the timing and strategy of the surgical treatment are determined by evaluating fracture type, status of the peripheral soft tissue structures, bone quality, accompanying neurovascular injury, joint involvement, general status of the patient, experience of the surgeon and availability of the equipment.

Poor vascularity of soft tissues and bone at the distal tibia level, and the absence of muscles covering this region puts the reconstructive affords in danger by means of complications related to inadequate soft tissue coverage after bone fixation (6). Absorption of the energy by soft tissues at the site of injury, which results in extensive damage, is directly linked to higher complication rates (13). Early complications include skin necrosis, infection, hematoma, neurovascular injury, compartment syndrome and thrombophlebitis, whereas nonunion, malunion, osteomyelitis, post-traumatic arthrosis, Sudeck's atrophy, tarsal tunnel syndrome, tibiofibular synostosis might be seen in long-term at variable rates. Among these complications, wound infection in the early postoperative period deserves special consideration, since it may require revision surgeries, which might end up with serious long term complications such as arthrodesis and amputation of the involved lower extremity (14). Patients, who are smokers and have history of diabetes, are more prone to develop complications $(1,15)$. The presence of uncontrolled diabetes increases the complication rate 3.8 times, and the chance of revision surgery 5 times (16).

Fracture blisters may form over the fracture site due to rapidly progressing edema and soft tissue damage. A fracture blister may be either serous or hemorrhagic $(17,18)$. The former indicates superficial damage, while the latter points full thickness dermal damage.Inthepresenceofblisters, re-epithelialization process should be waited to be complete before the surgery. If it is not the case, the incisions must be planned far away from the blisters (19). When the edema starts to regress, the skin color returns to normal, and the skin wrinkles become visible (20). In order to prevent further soft tissue damage, tissues should be retracted gently, the tourniquet time should be as short as possible and the skin closure must not be tight (19). Superficial skin necrosis secondary to surgery can be treated with local wound care. Patients, who develop mild cellulitis and limited erythematous areas, should receive oral antibiotics (19). If the cellulitis and erythema do not regress, in fact continues to progress, intravenous antibiotics should be administered, until the symptoms resolve (21). Infectious diseases consultation should be kept in mind in cases with special considerations. Once a superficial infection occurs in a patient, it increases the risk of deep 
infection 6 times (8). If the infection at the operative field jeopardizes the stability of the bone fixation, depending on the method used, foreign materials should be removed and external fixation must be applied. If the bone is exposed, but the fixation is still stable, the defect must be debrided first, and then should be covered with either local or free tissue transfer, meanwhile the patient should receive intravenous antibiotics 3 to 6 weeks (21). Sometimes osteomyelitis is not preventable despite all the treatment efforts, requiring below-knee amputation in such cases (21).

In the postoperative period soft tissue problems in variable degrees may be encountered, especially in high-energy fractures, even though all the preoperative issues are considered, and the surgery is performed meticulously. Depending on the size and status of the defect, it can be covered with skin graft, local flap, pedicled fasciocutaneous flap, cross-leg flap, propeller flap or free flap $(22,23)$. Skin grafts are useful, where the defect is limited to dermis and subcutaneous tissue, however it is inadequate for defects with exposed bone. Vascular damage due to trauma is a major obstacle for reconstruction with local, pedicled and propeller flaps. Cross leg flaps are not preferred, since it has a short pedicle and limited arc of rotation and necessitates immobilization at least for 2 weeks. Free flap is suitable for large and complex defects, however for optimal outcome, an experienced surgeon with microsurgical skills is needed. Long operative time and risk of total flap loss are the other disadvantages of this procedure $(24,25)$.

The use of neurocutaneous flaps in extremity defects, was first described in 1992 by Masquetlet (26). The sural nerve travels from the space between the two heads of gastrocnemius muscle, down to the ankle where it is located between lateral malleolus and the Achilles tendon. The circulation of the nerve, thus the sural flap, is provided by sural artery at the proximal level, and by perforator vessels coming from the fibular artery at the distal level (27). The last perforator arising from the fibular artery is located 5 to $7 \mathrm{~cm}$ proximal to lateral malleolus, in the posterior aspect of the fibula. When the sural flap is designed with its base at the distal region, the latter is considered as the pedicle, which supplies the flap in a reverse fashion (24). The perforator artery is located with hand-held Doppler device preoperatively. The venous drainage of the flap is maintained by small veins within the flap, which do not possess any valves (24). The procedure can be done under spinal anesthesia safely. The flap size is suitable for small to moderate defects, whereas it may not provide enough coverage for large defects (28). The most common complication of the sural flap is venous congestion, which can be relieved by elevation. Besides as long as the width of the pedicle is large enough, the risk of venous congestion decreases significantly (24). The major drawback of this flap is the visible scar at the flap donor site on the posterior leg. Hypoesthesia of the lateral aspect of foot resulting from the sural nerve sacrifice merely affects the quality of daily life and improves with time (29). Diabetes mellitus and venous or arterial insufficiency are the risk factors by means of flap viability and if a patient has all these risk factors at the same time, reconstruction with this flap is contraindicated due to increased risk for flap necrosis (27). Sural flap has a good mobility capacity and can be shaped according to the defect size without sacrificing important neurovascular structures.

\section{CONCLUSION}

Pilon fractures are among the most difficult fractures of the ankle to treat, and have a high complication rate. The extend of the soft tissue damage at the fracture site is one of the most important factors affecting the prognosis. Significant soft tissue damage also prevents the bone healing process by diminishing the regional blood supply. Recently, application of external fixators in the subacute period as the edema subsides at the operation site instead of early rigid fixation is advocated, which allows the plastic surgeon to reconstruct defects with sural flap in single or multiple stages in a more sufficient way. 


\section{REFERENCES}

1. Ovadia DN, Beals RK. Fractures of the tibial plafond. J Bone Joint Surg Am 1986; 68: 543-51. [CrossRef]

2. Borrelli J Jr, Ellis E. Pilon fractures: assessment and treatment. Orthop Clin North Am 2002; 33: 231-45. [CrossRef]

3. Bourne RB. Pylon fractures of the distal tibia. Clin Orthop Relat Res 1989; 240: 42-6. [CrossRef]

4. Akkaya MG, Okçu G. Tibia pilon kırıklarında tedavi. Turkiye Klinikleri J Surg Med Sci 2007; 3: 76-90.

5. Bourne RB, Rorabeck $\mathrm{CH}$, Macnab J. Intra-articular fractures of the distal tibia: the pilon fracture. J Trauma 1983; 23: 591-6. [CrossRef]

6. Helfet DL, Koval K, Pappas J, Sanders RW, DiPasquale T. Intraarticular "pilon" fracture of the tibia. Clin Orthop Relat Res 1994; 298: 221-8. [CrossRef]

7. Rüedi TP, Allgöwer M. The operative treatment of intra-articular fractures of the lower end of the tibia. Clin Orthop Relat Res 1979; 138: 105-10.

8. Teeny SM, Wiss DA. Open reduction and internal fixation of tibial plafond fractures. Variables contributing to poor results and complications. Clin Orthop Relat Res 1993; 292: 108-17.

9. Rüedi T. Fractures of the lower end of the tibia in to the ankle joint: results 9 years after open reduction and internal fixation. Injury 1973; 5: 130-4. [CrossRef]

10. Jergesen $F$. Open reduction of fractures and dislocations of the ankle. Am J Surg 1959; 98: 136-51. [CrossRef]

11. Gustilo RB, Anderson JT. Prevention of infection in thetreatment of one thousand and twenty-five open fractures of long bones: retrospective and prospective analyses. J Bone Joint Surg Am 1976; 58: 453-8. [CrossRef]

12. Gustilo RB, Mendoza RM, Williams DN. Problems in the management of type III (severe) open fractures: a new classification of type III open fractures. J Trauma 1984; 24: 7426. [CrossRef]

13. Ersan Ö, Çelik B, Kovalak E, Ateş Y. Tibia pilon kırıkları. Türk Ortopedi ve Travmatoloji Birliği Dergisi 2005; 4: 127-37.

14. Assal M, Ray A, Stern R. The extensile approach for the operative treatment of high-energy pilon fractures: surgical technique and soft-tissue healing. J Orthop Trauma 2007; 21: 198-206. [CrossRef]

15. White TO, Guy P, Cooke CJ, Kennedy SA, Droll KP, Blachut PA, et al. The results of early primary open reduction and internal fixation for treatment of OTA 43. C-type tibial pilon fractures: a cohort study. J Orthop Trauma 2010; 24: 757-63.

16. Wukich DK, Joseph A, Ryan M, Ramirez C, Irrgang JJ. Outcomes of ankle fractures in patients with uncomplicated versus complicated diabetes. Foot Ankle Int 2011; 32: 120-30. [CrossRef]
17. Giordano CP, Koval KJ. Treatment of fracture blisters: a prospective study of 53 cases. J Orthop Trauma 1995; 9: 171-6. [CrossRef]

18. Varela $C D$, Vaughan $T K$, Carr JB, Slemmons BK. Fracture blisters: clinical and pathological aspects. J Orthop Trauma 1993; 7: 417 27. [CrossRef]

19. Thordarson DB. Complications After Treatment of Tibial Pilon Fractures: Prevention and Management Strategies. I Am Acad Orthop Surg 2000; 8: 253-65. [CrossRef]

20. Liporace FA, Yoon RS. Decisions and staging leading to definitive open management of pilon fractures: where have we come from and where are we now? J Orthop Trauma 2012; 26: 488-98. [CrossRef]

21. Patzakis MJ: Management of osteomyelitis, In: Chapman MW, Medison M (eds). Operative Orthopaedics, 2nd ed. Philadelphia: Lippincott, 1993, vol 4, p. 3335-55.

22. Ruan HJ, Cai PH, Schleich AR, Fan CY, Chai YM. The extended peroneal artery perforator flap for lower extremity reconstruction. Ann Plast Surg 2010; 64: 451-7. [CrossRef]

23. Benito-Ruiz J, Yoon T, Guisantes-Pintos E, Monner J, SerraRenom JM. Reconstruction of soft-tissue defects of the heel with local fasciocutaneous flaps. Ann Plast Surg 2004; 52: 380-4. [CrossRef]

24. Liu L, Zou L, Li Z, Zhang Q, Cao X, Cai J. The extended distally based sural neurocutaneous flap for foot and ankle reconstruction: a retrospective review of 10 years of experience. Ann Plast Surg 2014; 72: 689-94. [CrossRef]

25. Karameşe $M$, Yıldıran GÜ, Akdağ $O$, Selimoğlu MN, Abacı M, Tosun Z. Ayak bileği ve topuk defektlerinde serbest free flap alternatifi: Geciktirme yapılmış, ters akımlı sural ada flebi. Turk Plast Surg 2015; 23: 27-32.

26. Masquetlet AC, Romana MC, Wolf G. Skin island flaps supplied by the vascular axis of the sensitive nerves: anatomic study and clinical experience in the leg. Plast Reconstr Surg 1992; 89: 1115-21. [CrossRef]

27. Grabb's Encylopedia of Flaps. In: Strauch B, Vasconez LO, HallFindlay E, Lee B (eds). Vol. 3, 3rd ed. Sural Flap. Philadelphia: Lippincott; 2009. p. 1480-3.

28. Dong ZG, Wei JW, Ni JD, Liu LH, Luo ZB, Zheng $L$, et al. Anterograde-retrograde method for harvest of distally based sural fasciocutaneous flap: report of results from 154 patients. Microsurgery 2012; 32: 611-6. [CrossRef]

29. Park JS, Roh SG, Lee NH, Yang KM. Versatility of the distallybased sural artery fasciocutaneous flap on the lower leg and foot in patients with chronic disease. Arch Plast Surg 2013; 40: 220-5. [CrossRef] 